\title{
FAKTOR-FAKTOR YANG MEMPENGARUHI KETEPATAN WAKTU PELAPORAN KEUANGAN PADA PERUSAHAAN MANUFAKTUR YANG TERDAFTAR DI BURSA EFEK INDONESIA TAHUN 2016-2017
}

\author{
JOANA L. SARAGIH ${ }^{1}$ \\ SIMON JEPRIANTO GULTOM² \\ ${ }^{1,2}$ Fakultas Ekonomi Program Studi Akuntansi Universitas Katolik Santo Thomas \\ $\underline{\text { saragihjoana@gmail.com }}{ }^{1}$, simonjeprigultom@gmail.com ${ }^{2}$
}

\begin{abstract}
ABSTRAK
Penelitian ini bertujuan untuk mengetahui pengaruh ukuran perusahaan, kompleksitas operasi, struktur kepemilikan dan leverage terhadap ketepatan waktu penyampaian laporan keuangan pada perusahaan manufaktur yang terdaftar di Bursa Efek Indonesia. Rumusan masalah dalam penelitian ini adalah "Apakah ukuran perusahaan, kompleksitas operasi, struktur kepemilikan dan leverage berpengaruh terhadap ketepatan waktu penyampaian laporan keuangan pada perusahaan manufaktur yang terdaftar di Bursa Efek Indonesia?". Hipotesis yang dikemukakan adalah ukuran perusahaan dan Struktur kepemilikan secara persial berpengaruh positif terhadap ketepatan waktu penyampaian laporan keuangan sedangkan, kompleksitas operasi dan leverage secara persial berpengaruh negatif terhadap ketepatan waktu penyampaian laporan keuangan pada perusahaan manufaktur yang terdaftar di Bursa Efek Indonesia. Teknik pengambilan sampel yang digunakan adalah purposive sampling dengan jumlah sampel sebanyak 97 perusahaan. Data diperoleh dari Bursa Efek Indonesia tahun 2016-2017. Teknik analisis data yang digunakan adalah regresi logistik dengan tingkat signifikansi sebesar 5\%.Hasil uji secara parsial menunjukkan bahwa ukuran perusahaan dan kompleksitas operasi tidak berpengaruh signifikan terhadap ketepatan waktu penyampaian laporan keuangan sedangkan struktur kepemilikan dan leverage berpengaruh signifikan terhadap ketepatan waktu penyampaian laporan keuangan. Hasil uji secara simultan menunjukkan bahwa ukuran perusahaan, kompleksitas operasi, struktur kepemilikan dan leverage berpengaruh signifikan terhadap ketepatan waktu penyampaian laporan keuangan. Berdasarkan hasil Nagerkerke R Square sebesar 0,318 atau 31,8\% artinya masih banyak variabel lain yang dapat mempengaruhi ketepatan waktu penyampaian laporan keuangan. Oleh karena itu, penulis menyarankan agar peneliti selanjutnya menambahkan variabel lain seperti kualitas auditor, dan sebagainya serta menambah periode penelitian. Walaupun ada peraturan mengenai tanggal penyampaian laporan keuangan, namun masih ada perusahaan yang tidak tepat waktu.
\end{abstract}

Kata kunci : Tepat waktu, ukuran perusahaan, kompleksitas operasi, struktur kepemilikan dan leverage.

\section{PENDAHULUAN}

Pasar modal mempunyai peranan yang penting bagi perekonomian disuatu Negara. Bisnis investasi ini akan menjadi sedemikian kompleks dengan tingkat persaingan yang semakin ketat. Terutama dalam upaya penyediaan dan perolehan informasi dalam setiap pengambilan keputusan. Salah satu sumber informasi penting dalam bisnis investasi di pasar modal adalah laporan keuangan yang disediakan setiap perusahaan yang Go Publik. Laporan keuangan merupakan salah satu media yang dirancang untuk memberikan informasi-informasi dan pengukuran secara ekonomi mengenai sumber daya dan kinerja yang dimiliki oleh suatu perusahaan kepada calon investor, calon kreditor, manajemen perusahaan dan pengguna laporan keuangan lainnya untuk pengambilan keputusan. mengingat pentingnya kebutuhan informasi laporan keuangan yang disajikan tepat waktu, maka perusahaan-perusahaan 
manufaktur go public yang terdaftar di Bursa Efek Indonesia (BEI) wajib mempublikasikan laporan keuangan tahunan kepada Otoritas Jasa Keuangan dan mengumumkan kepada masyarakat. Hal ini disebabkan karena munculnya aturan yang dikeluarkan oleh OJK pada tahun 2016, yaitu menerbitkan Peraturan Otoritas Jasa Keuangan Nomor: 29/POJK.04/2016, yang mewajibkan bagi setiap emiten dan perusahaan publik untuk menyampaikan laporan keuangan tahunan perusahaan kepada OJK selambat-lambatnya pada akhir bulan keempat (120 hari) setelah tahun buku berakhir.

Sehubungan dengan kewajiban penyampaian laporan keuangan, OJK juga mengatur tentang sanksi bagi pihak yang melanggar peraturan OJK tentang laporan tahunan emiten. sanksi tersebut berupa peringatan tertulis, denda yaitu kewajiban untuk membayar sejumlah uang tertentu, pembatasan kegiatan usaha, pembekuan kegiatan uasaha, pencabutan ijin usaha, pembatalan persetujuan, dan pembatalan pendaftaran. Bursa Efek Indonesia juga mengatur sanksi bagi perusahaan yang tidak tepat waktu dalam menyampaikan laporan keuangannya, yaitu:

1. Peringatan tertulis 1 atas keterlambatan sampai akhir bulan berikutnya

2. Peringatan tertulis 2 dan denda sebesar Rp 10.000 .000 atas keterlambatan dari awal bulan ke-2 sampai dengan akhir bulan ke-2 sejak batas waktu penyampaian laporan keuangan.

3. Peringatan tertulis 3 dan denda sebesar Rp 30.000 .000 atas keterlambatan dari awal bulan ke-3 sampai akhir bulan ke-3 sejak batas waktu penyampaian laporan keuangan.

4. Suspensi, apabila mulai awal bulan ke-4 (empat) sejak batas waktu penyampaian laporan keuangan, Perusahaan Tercatat tetap tidak memenuhi kewajiban penyampaian laporan keuangan dan atau Perusahaan Tercatat telah menyampaikan laporan keuangan namun tidak memenuhi kewajiban untuk membayar denda sebagaimana dimaksud.

Ketepatan waktu diukur menggunakan variabel dummy yang berarti jika tepat waktu maka diberi kategori 1 dan jika tidak tepat waktu diberi kategori 0. Dikatakan tepat waktu apabila laporan keuangan disampaikan paling lambat pada akhir bulan keempat atau 120 hari setelah tahun buku berakhir dan dikatakan tidak tepat waktu apabila laporan keuangan disampaikan lebih dari 120 hari setelah tahun buku berakhir.Tujuan dari penelitian ini adalah untuk mengetahui pengaruh ukuran perusahaan, kompleksitas operasi, struktur kepemilikan dan Leverage terhadap ketepatan waktu penyampaian laporan keuangan pada perusahaan Manufaktur yang terdaftar di Bursa Efek Indonesia.

\section{TINJAUAN PUSTAKA DAN HIPOTESIS}

\section{Teori Kepatuhan (Compliance Theory)}

Tuntutan akan kepatuhan terhadap ketepatan waktu dalam penyampaian laporan keuangan tahunan perusahaan publik di Indonesia diatur dalam Peraturan Otoritas Jasa Keuangan Nomor 29/POJK-04/2016 menyatakan bahwa laporan keuangan tahunan wajib disertai dengan laporan akuntan dalam rangka audit atas laporan keuangan dan disampaikan kepada OJK dan diumumkan kepada masyarakat paling lambat pada akhir bulan keempat setelah tahun buku berakhir. Peraturan ini mengisyaratkan kepatuhan setiap pelaku individu maupun organisasi (perusahaan publik) yang terlibat di pasar modal Indonesia untuk menyampaikan laporan keuangan tahunan perusahaan secara tepat waktu kepada OJK. Hal tersebut sesuai dengan teori kepatuhan (compliance theory).Teori kepatuhan mendorong perusahaan untuk berusaha menyampaikan laporan keuangan secara tepat waktu karena selain merupakan kewajiban perusahaan untuk menyampaikan laporan keuangan tepat waktu, juga akan bermanfaat bagi para pengguna laporan. 


\section{Teori Keagenan (Agency Theory)}

Teori keagenan (theory agency) adalah teori yang menguraikan Pengaruh antara principal dan agent. Dalam penelitian ini pihak principal bisa dikatakan sebagai investor sedangkan pihak agen adalah manajer. Dalam teori keagenan, Pengaruh agency muncul ketika satu orang atau lebih (principal) mempekerjakan orang lain (agent) untuk memberikan suatu jasa dan kemudian mendelegasikan suatu wewenang pengambilan keputusn kepada agen tersebut. Oleh sebab itu, agen berkewajiban memberikan informasi mengenai kondisi perusahaan kepada principal. Salah satu bentuk informasi yang diberikan adalah pengungkapan informasi akuntansi seperti laporan keuangan. Pengaruh antara pihak agen dan principal berada pada kondisi ketidakseimbangan (asimetri) informasi karena agen berada pada posisi yang memiliki informasi yang lebih banyak tentang perusahaan dibandingkan pihak principal. Pihak agen akan berusaha memaksimalkan kepentingan mereka sendiri, sehingga dengan asimetri yang dimilikinya akan mendorong agen untuk menyembunyikan beberapa informasi yang tidak diketahui principal. Oleh karena itu, dengan menerbitkan laporan keuangan secara tepat waktu akan meminimalisir terjadinya asimetri informasi antara pihak principal dan pihak agen.

Laporan keuangan menurut Kasmir (2012) merupakan Laporan yang menunjukkan kondisi keuangan perusahaan pada saat ini atau dalam suatu periode tertentu. Maksud dari laporan keuangan yang menunjukkan kondisi perusahaan saat ini adalah merupakan kondisi keuangan perusahaan terkini. Kondisi perusahaan terkini adalah keadaan keuangan perusahaan pada tanggal tertentu (untuk neraca) dan periode tertentu (untuk laporan laba rugi). Tujuan laporan keuangan menurut IAI (2009) adalah menyediakan informasi yang menyangkut posisi keuangan, kinerja, serta perubahan posisi keuangan suatu perusahaan yang bermanfaat bagi sejumah besar pemakai dalam pengambilan keputusan ekonomi.Menurut Suwito dan Herawaty dalam Nasution, (2013) Ukuran Perusahaan merupakan gambaran besar kecilnya perusahaan yang ditentukan berdasarkan sebuah ukuran yang dapat dinilai. Besar kecilnya ukuran perusahaan dapat dilihat dari total aktva, total penjualan dan juga dipengaruhi oleh operasional dan intensitas perusahaan. Dalam penelitian ini ukuran perusahaan diukur dengan logaritme natural total aktiva.

Total aktiva dipilih sebagai proksi atas ukuran perusahaan dengan mempertimbangkan bahwa nilai aktiva relatif lebih stabil dibanding nilai market capitalized dan penjualan. semakin besar nilai asset perusahaan, maka akan semakin cepat penyampaian laporan auditan dan sebaliknya.Hal ini didukung oleh Penelitian R. Ait Novatiani dan Nadia Putri A(2016) yang mengatakan bahwa ukuran perusahaan berpengaruh terhadap ketepatan waktu pelaporan keuangan. Penelitian tersebut menunjukkan bahwa perusahaan yang memiliki ukuran perusahaan yang semakin besar akan semakin tepat waktu dalam menyampaikan laporan keuangan dibanding perusahaan yang memliki ukuran perusahaan kecil. Maka hipotesis yang dapat disusun adalah sebagai berikut :

H1: Ukuran Perusahaan Berpengaruh positif terhadap Ketepatan Waktu Penyampaian Laporan Keuangan

Menurut Martius (2012) Kompleksitas organisasi atau operasi merupakan akibat dari pembentukan departemen dan pembagian pekerjaan yang memiliki fokus terhadap jumlah unit yang berbeda. Ketergantungan yang semakin kompleks terjadi apabila organisasi dengan berbagai jenis atau jumlah pekerjaan dan unit menimbulkan masalah manajerial dan organisasi yang lebih rumit. Tingkat kompleksitas operasi sebuah perusahaan yang bergantung pada jumlah dan lokasi unit operasinya (cabang) serta diversifikasi jalur produk dan pasarnya, lebih cenderung mempengaruhi waktu yang dibutuhkan auditor untuk menyelesaikan pekerjaan auditnya. Sehingga hal tersebut juga mempengaruhi ketepatan waktu penyampaian laporan keuangan perusahaan kepada publik. Hal ini didukung oleh Penelitian R. Ait Novatiani dan Nadia Putri A(2016) yang mengatakan bahwa kompleksitas 
operasi berpengaruh terhadap ketepatan waktu pelaporan keuangan. Penelitian tersebut menunjukkan bahwa perusahaan yang memiliki anak perusahaan akan cenderung tidak tepat waktu dalam menyampaikan laporan keuangan dibanding perusahaan yang tidak memliki anak perusahaan. Maka hipotesis yang dapat disusun adalah sebagai berikut :

H2 : Kopleksitas Operasi berpengaruh negatif terhadap ketepatan waktu penyampaian laporan keuangan

Menurut Marwata dalam Widaryanti (2011) struktur kepemilikan adalah struktur kepemilikan saham yaitu perbandingan jumlah saham yang dimiliki oleh orang dalam (insider) dengan jumlah saham yang dimiliki oleh investor. Atau dengan kata lain struktur kepemilikan saham adalah proporsi kepemilikan institusional dan kepemilikan manajemen dalam kepemilikan saham perusahaan. Dalam menjalankan kegiatannya suatu perusahaan diwakili oleh direksi (agents) yang ditunjuk oleh pemegang saham (principals). Semakin tinggi atau besar kepemilikan saham publik dalam suatu perusahaan maka perusahaan akan menyampaikan informasi perusahaanya secara tepat waktu karena banyaknya dari masyarakat membutuhkan informasi tersebut.Hal ini didukung oleh Penelitian I G A P Bunga V dan Gayatri(2018) yang mengatakan bahwa struktur kepemilkan publik berpengaruh terhadap ketepatan waktu pelaporan keuangan. Penelitian tersebut menunjukkan bahwa perusahaan yang memiliki persentase kepemilikan publik yang lebih besar akan cenderung tepat waktu dalam menyampaikan laporan keuangan dibanding perusahaan yang memliki persentase kepemilikan publik yang lebih kecil. Maka hipotesis yang dapat disusun adalah sebagai berikut:

H3 : Struktur Kepemilikan berpengaruh positif terhadap ketepatan waktu penyampaian laporan keuangan

Menurut Kasmir (2012) Rasio Leverage adalah rasio yang digunakan untuk mengukur sejauh mana aktivita perusahaan dibiayai oleh hutang. Artinya, berapa besar beban utang yang ditanggung perusahaan dibandingkan dengan aktivanya. Dalam penelitian ini, leverage diukur dengan DAR (Debt To Asset Ratio) yaitu dengan membandingkan total hutang dengan total aktiva. Pengukuran dengan DAR dapat menggambarkan tingkat penggunaan hutang dalam struktur total aktiva suatu perusahaan yang bisa memberikan tingkat pengembalian lebih tinggi.Dari hasil pengukuran, apabila rasionya tinggi (berada diatas rata-rata industry 35\% 0,35 ) artinya pendanaan dengan utang semakin banyak, maka semakin sulit bagi perusahaan untuk memperoleh tambahan pinjaman karena dikhawatirkan perusahaan tidak mampu menutupi utang-utangnya dengan aktiva yang dimilikinya, hal ini merupakan berita buruk bagi perusahaan, sehingga perusahaan akan tidak tepat waktu dalam penyampaian laporan keuangnnya, dibandingkan dengan perusahaan yang mendapat tingkat DAR dibawah rata-rata industry, karena hal ini merupakan berita baik, sehingga perusahaan akan lebih tepat waktu penyampaian laporan keuangannya. Hal ini didukung oleh Penelitian R. Ait Novatiani dan Nadia Putri A(2016) yang mengatakan bahwa leverage berpengaruh terhadap ketepatan waktu pelaporan keuangan. Penelitian tersebut menunjukkan bahwa semakin rendah leverage perusahaan akan tepat waktu dalam menyampaikan laporan keuangan dibanding perusahaan yang leverage nya tinggi. Maka hipotesis yang dapat disusun adalah sebagai berikut :

H4: Leverage berpengaruh negatifterhadap ketepatan waktu penyampaian laporan keuangan

\section{METODE PENELITIAN \\ Ruang Lingkup Penelitian}

Ruang lingkup penelitian yang dipilih oleh penulis yaitu perusahaan Manufaktur yang terdaftar di bursa efek Indonesia tahun 2016-2017. Penelitian ini dilakukan melalui situs www.idx.co.id dan www. IDNfinancials.com. Data yang digunakan dalam penelitian ini 
adalah data sekunder dengan teknik dokumentasi yang diperoleh melalui laporan keuangan yang dipublikasikan di Bursa Efek Indonesia.

\section{Populasi Dan Sampel}

Populasi adalah wilayah generalisasi yang terdiri atas obyek atau subyek yang mempunyai kualitas dan karakteristik tertentu yang ditetapkan oleh peneliti untuk dipelajari dan kemudian ditarik kesimpulan (Sugiyono, 2015:115). Populasi dalam penelitian ini adalah perusahaan manufaktur yang terdaftar di Bursa Efek Indonesia (BEI) tahun 2016-2017 sebanyak 149 perusahan.

Sampel diambil dengan menggunakan purposive sampling, teknik ini dilakukan dengan cara memilih sampel dari suatu populasi berdasarkan pada informasi yang tersedia . Adapun kriteria sampel dalam penelitian ini adalah:

1. Perusahaan manufaktur yang terdaftar di BEI secara berturut-turut pada periode 20162017.

2. Perusahaan tersebut telah menerbitkan laporan keuangan auditan dan dipublikasikan periode 2016-2017.

3. Perusahaan yang menggunakan mata uang Rupiah.

4. Perusahaan yang tidak menampilkan data dan informasi yang digunakan untuk menganalisis pengaruh ketepatan waktu penyampaian laporan keuangan untuk periode 2016-2017 Jumlah sampel yang diperoleh dalam penelitian ini adalah sebanyak 97 perusahaan.

\section{Operasional Variabel}

\section{a. Ketepatan Waktu Pelaporan Keuangan (Variabel Dependen)}

Variabel terikat yaitu variabel yang dipengaruhi oleh variabel lain. Variabel terikat dalam penelitian ini adalah ketepatan waktu, Ketepatan waktu diukur menggunakan variabel dummy yang berarti jika tepat waktu maka diberi kategori 1 dan jika tidak tepat waktu diberi kategori 0. Dikatakan tepat waktu apabila laporan keuangan disampaikan paling lambat pada akhir bulan keempat atau 120 hari setelah tahun buku berakhir dan dikatakan tidak tepat waktu apabila laporan keuangan disampaikan lebih dari 120 hari setelah tahun buku berakhir.

\section{b. Ukuran Perusahaan}

Ukuran Perusahaan adalah suatu skala, dimana dapat diklasifikasikan besar kecilnya perusahaan menurut berbagai cara, antara lain: total aktiva, log size, nilai pasar saham, dan lain-lain. Pada penelitian ini, ukuran perusahaan diproksikan dengan menggunakan Ln total asset. Penggunaan natural log (Ln) di penelitian ini dimaksudkan untuk mengurangi fluktuasi data yang berlebihan. Penggunaan total aktiva sebagai alat ukuran perusahaan didasarkan pada penelitian R. Ait Novatiani dan Nadia Putri A (2016). Dalam peraturan OJK Ukuruan perusahaan yang didasarkan pada total assets yang dimiliki perusahaan menyatakan bahwa perusahaan menengah atau kecil adalah perusahaan yang memiliki jumlah kekayaan (total assets) tidak lebih dari 250 milyar rupiah atau jika di Ln kan 26,2447. Dalam penelitian ini, ukuran perusahaan dapat dinyatakan dengan rumus:

Ukuran Perusahaan $($ size $)=$ Ln Total Assets

\section{c. Kompleksitas Operasi}

Kompleksitas organisasi atau operasi merupakan akibat dari pembentukan departemen dan pembagian pekerjaan yang memiliki fokus terhadap jumlah unit yang berbeda. Pengukurannya menggunakan dummy, dimana perusahaan yang tidak memiliki anak perusahaan (cabang) akan diberi nilai 0 , dan perusahan yang memiliki anak perusahaan 
(cabang) akan mendapat nilai 1. Penggunaan pengukuran ini didasarkan pada penelitian R. Ait Novatiani dan Nadia Putri A (2016).

\section{d. Struktur Kepemilikan}

Struktur kepemilikan adalah persentase jumlah saham yang dimiliki oleh pihak luar seperti investor. Dengan adanya konsentrasi kepemilikan pihak luar maka akan mengubah pengelolaan perusahaan yang semula berjalan dengan sekehendak hati menjadi perusahaan yang berjalan dengan pengawasan. Dalam penelitan ini struktur kepemilikan perusahaan diukur dengan melihat dari seberapa besar persentase saham yang dimiliki oleh kepemilikan publik (masyarakat) pada perusahaan yang terdaftar di BEI. Penggunaan pengukuran ini didasarkan pada Penelitian I G A P Bunga V dan Gayatri (2018)

\section{e. Leverage}

Menurut Kasmir (2012:156) Rasio laverage atau solvabilitas merupakan rasio yang digunakan untuk mengukur sejauh mana aktiva perusahaan dibiayai dengan utang. Artinya, berapa besar beban utang yang ditanggung perusahaan dibandingkan dengan aktivanya. Kasmir meyatakann rata-rata industri untuk hasil DAR adalah 35\% atau 0,35. Penggunaan pengukuran ini didasarkan pada Penelitian Yohan A Hutabarat (2018). Dalam penelitian ini rasio leverage diukur dengan rumus sebagai berikut :

\section{Teknik Pengumpulan Data}

Data yang digunakan adalah data sekunder dengan teknik pengumpulan data dengan teknik dokumentasi. Data sekunder ini terdiri dari laporan auditor dan Ukuran Perusahaan, Kompleksitas Operasi, Srtuktur Kepemlikan, dan Leverage setiap perusahaan manufaktur yang terdaftar di BEI tahun 2016-2017 dan sesuai dengan kriteria pemilihan sampel.

\section{Teknik Analisis Data}

Teknik analisa data yang digunakan dalam penelitian ini adalah metode deskriptif. Metode deskriptif adalah untuk mengetahui karakteristik sampel yang digunakan dan menggambarkan variabel-variabel dalam penelitian. Analisis statistik deskriptif meliputi jumlah, sampel, nilai minimum, nilai maksimum, nilai rata-rata (mean) dan standar deviasi dan Regresi Logistic adalah regresi yang digunakan sejauh mana probabilitas terjadinya variabel dependen dapat diprediksi dengan variabel independen.Hasil Dan Pembahasan.

\section{HASIL DAN PEMBAHASAN Uji Deskriptif}

Berdasarkan pada tabel hasil uji deskriptif, menjelaskan dari total 194 sampel diperoleh hasil sebanyak 173 (89\%) sampel dari tiap perusahaan yang tepat waktu dalam menyampaikan laporan keuangannya, sedangkan 21 (11\%) tidak tepat waktu dalam menyampaikan laporan keuangan. Berarti sebagian besar perusahaan telah menyampaikan laporan keuangannya dengan tepat waktu.

Variabel Ukuran Perusahaan yang pada penelitian ini diproksikan dengan Logaritma Natural dari Total Asset (Ln Total Asset) menghasilkan nilai minimum 25,6635 yang dimiliki oleh PT. Kedaung Indah Can Tbk tahun 2016, sedangkan nilai maksimumnya adalah 31,8321 dimiliki oleh PT. Gudang Garam Tbk pada tahun 2017. Hal tersebut menunjukan bahwa perusahaan yang menjadi sampel memiliki total asset antara 25,6635 sampai dengan 31,8321. Nilai rata-rata variabel ukuran perusahaan adalah 28,371659 dengan standar deviasi sebesar 1,4031510 .

Variabel Kompleksitas Operasi memiliki nilai minimum 0,0000 dan maksimum 1,0000 dengan nilai rata-rata 0,7300 standar deviasi adalah sebesar 0,4470 . Jumlah data yang digunakan adalah sebanyak 194 
Variabel Struktur Kepemilikan memiliki nilai minimum 0,0023 dan maksimum 0,5922 dengan nilai rata-rata 0,2310 dan standar deviasi adalah sebesar 0,1437. Jumlah data yang digunakan adalah sebanyak 194.

Variabel Leverage memiliki nilai minimum 0,0769 dan maksimum 1,1088 dengan nilai rata-rata 0,4443 dan standar deviasi adalah sebesar 0,2087. Jumlah data yang digunakan adalah sebanyak 194.

\section{Uji Analisis Logistic Regression \\ Menilai Model Fit}

Untuk menganalisis hasil output data dari logistic regression dilakukan dengan menggunakan penilaian model fit. Langkah pertama yaitu dengan menilai overall fit model terhadap data. Hipotesis untuk menilai model fit adalah:

HO : Model yang dihipotesiskan fit dengan data

HA: Model yang dihipotesiskan tidak fit dengan data

\section{a. Fungsi Likelihood}

Dari tabel likelihood dapat dilihat bahwa nilai -2Llawal (Block $0=$ Beginning Block) adalah sebesar 133,020. Setelah dimasukkan keempat variabel independen, maka nilai 2LL akhir (Block 1; Method = Enter) mengalami penurunan menjadi 99,686. Penurunan Likelihood (-2LL) ini menunjukkan model regresi yang lebih baik atau dengan kata lain model yang dihipotesiskan fit dengan data. Artinya penambahan variabel bebas kedalam model penelitian akan memperbaiki model fit penelitian ini.

b. Cox dan Snell's R Square dan Negelkerke's R Square

Dilihat dari tabel nilai Cox dan Snell's R Square sebesar 0,158 dan nilai Negelkerke's R Square sebesar 0,318. Hasil tersebut menunjukkan bahwa variabilitas variabel dependen yang dapat dijelaskan oleh variabilitas variabel independen sebesar 31,8\%.

\section{c. Hosmer dan LemeshowGoodness of Fit Test}

Dalam tabel Hosmer dan LemeshowGoodness of Fit Test hasil pengujian nilai statistik Hosmer and Lemeshow's test adalah 12,630 dengan probabilitas signifikansi sebesar 0,125 lebih besar dari alpha $(\alpha=0.05)$, maka Ho diterima. Hal ini berarti model regresi layak untuk digunakan dalam analisis selanjutnya, karena tidak ada perbedaan yang nyata antara klasifikasi yang diprediksi dengan klasifikasi yang diamati atau dapat dikatakan bahwa model mampu memprediksi nilai observasinya.

\section{Tabel Klasifikasi}

Tampilan dalam tabel kalsifikasi tersebut menunjukkan kekuatan prediksi dari model regresi untuk memprediksi kemungkinan perusahaan menyampaikan laporan keuangan tepat waktuadalah sebesar 98,3\%. Hal ini menunjukkan bahwa dengan menggunakan model regresi tersebut, terdapat sebanyak 170 perusahaan yang diprediksi akan menyampaikan laporan keuangannya tepat waktu sedangkan hasil observasi terdapat 173 perusahaan yang menyampaikan laporan keuangannya tepat waktu. Dapat juga dilihat, bahwa menurut prediksi perusahaan yang menyampaikan laporan keuangannya tidak tepat waktu sebanyak 4 perusahaan, sedangkan observasi sesungguhnya menunjukkan bahwa perusahaan yang menyampaikan laporan keuangannya tidak tepat waktu adalah 21 perusahaan. Jadi ketepatan model ini adalah $19 \%$

\section{Pengujian Hipotesis}

Dari Tabel diatas dapat diperoleh persamaan regresi logistik sebagai berikut:

Variabel konstan dalam model regresi mempunyai koefisien negatif sebesar -1,858 yang berarti jika variabel lain dianggap tetap maka ketepatan waktu penyampaian laporan keuangan mengalami penurunan sebesar $-1,858$ satuan. 
a. Pengaruh Ukuran Perusahaan Terhadap Ketepatan Waktu Penyampaian Laporan Keuangan. Dari persamaan regresi logistik di atas untuk variabel Ukuran Perusahaan yang dihitung dengan me Ln dari Total Asset diperoleh nilai koefisien regresi bertanda positif sebesar 0,314 artinya semakin tinggi Ukuran Perusahaan maka semakin tinggi probabilitas perusahaan tepat waktu menyampaikan laporan keuangannya. Nilai Exp (B) sebesar 1,369 artinya setiap kenaikan Ln Total Asset 1 persen maka probabilitas ketepatan waktu penyampaian laporan keuangan sebesar 1,369 kali dengan asumsi variabel lain konstan. Tabel hasil regresi logistic memberikan informasi bahwa Ukuran Perusahaan memiliki nilai beta positif sebesar 0,314 dan nilai signifikan sebesar 0,179> taraf signifikansi $\alpha=5 \%(0,05)$. Dari hasil tersebut dapat disimpulkan bahwa Ukuran Perusahaan memiliki pengaruh positif tetapi tidak signifikan terhadap ketepatan waktu penyampaian laporan keuangan. Sehingga hipotesis yang menyatakan Ukuran Perusahaan berpengaruh terhadap ketepatan waktu penyampaian laporan keuangan ditolak. Dalam penelitian ini Ukuran perusahaan berpengaruh positf tapi tidak signifikan terhadap ketepatan waktu penyampaian laporan keuangan, artinya tinggi rendahnya Ln Total Asset yang dimiliki suatu perusahaan tidak menjadi pertimbangan perusahaan dalam menyampaikan laporan keuangan tepat waktu. Karena sering terjadi perusahaan yang memiliki ukuran yang besar menganggap bahwa cepat atau lambat mereka dalam menyampaikan laporan keuangan tidak terlalu mempengaruhi kepercayaan stakeholder terhadap perusahaan. Kemudian pemilihan sampel dan jangka tahun yang diteliti dalam penelitian ini juga dapat menyebabkan hasil dari penelitian ini tidak signifikan. Hasil penelitian ini didukung oleh penelitian Widia Astuti \& Teguh Erawati (2018) yang menyatakan bahwa ukuran perusahaan tidak berpengaruh secara signifikan terhadap ketepatan waktu penyampaian laporan keuangan. Namun hasil penelitian ini tidak sesuai dengan penelitian yang dilakukan R. Ait Novatiani dan Nadia Putri A (2016) yang menyatakan bahwa ukuran perusahaan berpengaruh signifikan terhadap ketepatan waktu penyampaian laporan keuangan. Hasil penelitian ini sejalan dengan teori yang dikatakatan oleh Suwito dan Herawaty dalam Nasution, (2013) perusahaan yang memiliki ukuran perusahaan yang besar akan cenderung menyampaikan laporan keuangannya tepat waktu atau semakin tinggi Ln Total Asset maka semakin cenderung tepat waktu pelaporan keuangannya.

b. Pengaruh Kompleksitas Operasi terhadap ketepatan waktu penyampaian laporan keuangan

Dari persamaan regresi logistik di atas untuk variabel Kompleksitas Operasiyang dihitung degan ada tidaknya anak perusahaan diperoleh nilai koefisien regresi bertanda negatif sebesar -0,111 artinya semakin perusahaan memiliki anak cabang maka semakin rendah probabilitas perusahaan tepat waktu menyampaikan laporan keuangannya. Nilai Exp (B) sebesar 0,895 artinya setiap kenaikan Kompleksitas Operasi 1 persen maka probabilitas ketepatan waktu penyampaian laporan keuangan sebesar 0,895 kali dengan asumsi variabel lain konstan. Tabel hasil regresi logistic memberikan informasi bahwa Kompleksitas Operasi memiliki nilai beta negatif sebesar -0,111 dengan nilai signifikan sebesar $0,863>$ taraf signifikansi $\alpha=5 \% \quad(0,05)$, maka dapat disimpulkan bahwa Kompleksitas Operasi berpengaruh negatif tetapi tidak signifikan terhadap ketepatan waktu penyampaian laporan keuangan. Sehingga hipotesis yang menyatakan Kompleksitas Operasi berpengaruh terhadap ketepatan waktu penyampaian laporan keuangan ditolak. Dalam penelitian ini Kompleksitas Operasi berpengaruh negatif tapi tidak signifikan terhadap ketepatan waktu penyampaian laporan keuangan, Artinya dalam penelitian ini jumlah anak (cabang) suatu perusahaan tidak berpengaruh terhadap ketepatan waktu suatu perusahaan dalam laporan keuangannya, karena semakin canggihnya teknologi diwaktu sekarang dapat membuat perusahaan lebih mudah dalam 
menyusun laporan konsolidasi, kemudian jumlah sampel dan jangka tahun yang diteliti juga dapat mengakibatkan hasil penelitian ini menjadi tidak signifikan. Namun penelitian ini konsisten dengan teori yang dikatakan oleh Martius (2012) menyatakan semakin ada anak suatu perusahaan maka perusahaan tersebut tidak tepat waktu dalam penyampaian laporan keuangan perusahaan. Hasil penelitian ini didukung oleh penelitian Apri Fajar (2017) yang menyatakan bahwa kompleksitas operasi tidak berpengaruh secara signifikan terhadap ketepatan waktu penyampaian laporan keuangan. Namun hasil penelitian ini tidak sesuai dengan penelitian yang dilakukan R. Ait Novatiani dan Nadia Putri A (2016) yang menyatakan bahwa kompleksitas operasi berpengaruh signifikan terhadap ketepatan waktu penyampaian laporan keuangan.

c. Pengaruh Struktur Kepemilikan Terhadap Ketepatan Waktu Penyampaian Laporan Keuangan

Dari persamaan regresi logistik diatas untuk Variabel Struktur Kepemilikan yang dihitung dari jumlah kepemilikan publik (masyarakat) diperoleh nilai koefisien regresi bertanda negatif sebesar -6,257 artinya semakin tinggi Kepemilikan Publik maka semakin rendah probabilitas ketepatan waktu penyampaian laporan keuangan. Nilai Exp (B) sebesar 0,002 artinya setiap kenaikan Kepemilikan Publik 1\% maka probabilitas ketepatan waktu penyampaian laporan keuangan sebesar 0,002 kali dengan asumsi variabel lain konstan. Tabel hasil regresi logistic memberikan informasi bahwa Struktur Kepemilikan memiliki nilai beta sebesar -6,257 dengan nilai signifikan sebesar 0,014 < dari taraf signifikansi $\alpha=5 \%(0,05)$, maka dapat disimpulkan bahwa Struktur Kepemilikan memiliki pengaruh negatif dan signifikan terhadap ketepatan waktu penyampaian laporan keuangan. Sehingga hipotesis yang menyatakan Struktur Kepemilikan berpengaruh terhadap ketepatan waktu penyampaian laporan keuangan diterima. Dalam penelitian ini Struktur Kepemilikan berpengaruh negatif tapi signifikan terhadap ketepatan waktu penyampaian laporan keuangan, artinya dalam penelitian ini semakin sedikit kepemilikan saham oleh publik semakin tepat waktu dalam penyampaian laporan keuangan. Hal ini membuktikan bahwa perusahaan yang tepat waktu tidak sepenuhnya dipengaruhi oleh saham kepemilikan pihak luar, karena saham kepemilikan pihak luar dalam suatu perusahaan memiliki nilai kurang dari 50\%, sehingga pihak luar tidak memiliki wewenang penuh dalam mengawasi perusahaan untuk menyampaikan laporan keuangan secara tepat waktu Penelitian ini sejalan dengan I G A P Bunga V dan Gayatri (2018) yang menyatakan bahwa struktur kepemilkan berpengaruh secara signifikan terhadap ketepatan waktu penyampaian laporan keuangan. Namun hasil penelitian ini tidak sesuai dengan penelitian yang dilakukan Puput Safitri (2013) yang menyatakan bahwa struktur kepemilikan tidak berpengaruh signifikan terhadap ketepatan waktu penyampaian laporan keuangan.

d. Pengaruh Leverage Terhadap Ketepatan Waktu Penyampaian Laporan Keuangan

Dari persamaan regresi logistik diatas untuk variabel Leverage yang dihitung dengan menggunakan variabel DAR diperoleh nilai koefisien regresi bertanda negatif sebesar 6,020 artinya semakin tinggi Leverage maka semakin rendah probabilitas ketepatan waktu penyampaian laporan keuangan. Nilai Exp (B) sebesar 0,002 artinya setiap kenaikan Leverage 1\% maka probabilitas ketepatan waktu penyampaian laporan keuangan sebesar 0,002 kali dengan asumsi variabel lain konstan. Dari tabel hasil regresi logistic memberikan informasi bahwa Leverage memiliki nilai beta sebesar -6,020 dan nilai signifikan sebesar $0,001>$ taraf signifikansi $\alpha=5 \%(0,05)$. Dari hasil tersebut dapat disimpulkan bahwa Leverage memiliki pengaruh negative dan signifikan terhadap ketepatan waktu penyampaian laporan keuangan. Sehingga hipotesis yang menyatakan Leverage berpengaruh terhadap ketepatan waktu penyampaian laporan keuangan diterima. Artinya semakin rendah leverage suatu perusahaan maka perusahaan cenderung 
semakin tepat waktu dalam menyampaikan laporan keuangannya dan semakin tinggi leverage suatu perusahaan maka perusahaan cenderung semakin tidak tepat waktu dalam menyampaikan laporan keuangannya. Penelitian ini sejalan dengan Puput Safitri (2013) yang menyatakan bahwa leverage berpengaruh secara signifikan terhadap ketepatan waktu penyampaian laporan keuangan. Namun hasil penelitian ini tidak sesuai dengan penelitian yang dilakukan I G A P Bunga V dan Gayatri (2018) yang menyatakan bahwa leverage tidak berpengaruh signifikan terhadap ketepatan waktu penyampaian laporan keuangan Penelitian ini juga sejalan dengan teori yang dikemukakan oleh Kasmir (2012) yang menyatakan bahwa semakin tinggi leverage suatu perusahaan yang berarti pendanaan dengan hutang semakin banyak, maka semakin sulit bagi perusahaan untuk memperoleh tambahan pinjaman karena dikhawatirkan perusahaan tidak mampu menutupi utang-utangnya dengan aktiva yang dimilikinya, hal ini merupakan berita buruk bagi perusahaan, sehingga perusahaan akan tidak tepat waktu dalam penyampaian laporan keuangnnya.

e. Pengaruh Ukuran Perusahaan, Kompleksitas Operasi, Struktur Kepemilikan, Dan Leverage terhadap Ketepatan Waktu Penyampaian Laporan Keuangan

Dari tabel 4.15 diatas dapat dilihat bahwa tingkat signifikansi sebesar $0,001<$ taraf signifikansi $\alpha=5 \%(0,05)$, sehingga dapat disimpulkan bahwa secara bersama-sama variabel ukuran perusahaan, kompleksitas operasi, struktur kepemilikan, dan leverage memiliki pengaruh terhadap ketepatan waktu penyampaian laporan keuangan.

\section{KESIMPULAN DAN SARAN \\ Kesimpulan}

Berdasarkan analisis dan pembahasan yang dilakukan terhadap 194 sampel perusahaan manufaktur dengan tahun penelitian 2016 sampai dengan 2017, maka diperoleh kesimpulan sebagai berikut:

1. Ukuran Perusahaan berpengaruh positif dengan nilai $\beta=0,314$ dan tidak berpengaruh signifikan dengan nilai Probabilitas 0,179 terhadap ketepatan waktu pelaporan keuangan. Ini berarti semakin tinggi Ln Total Asset maka perusahaan lebih cenderung tepat waktu dalam penyampaian laporan keuangan ke OJK tetapi tidak memberikan pengaruh yang signifikan. Maka hipotesis yang menyatakan Ukuran Perusahaan berpengaruh terhadap ketepatan waktu pelaporan keuangan Ditolak.

2. Kompleksitas Operasi berpengaruh negatif dengan nilai $\beta=-0.111$ dan tidak signifikan (nilai probabilitas $0.863>0.05$ ) terhadap ketepatan waktu pelaporan keuangan. Ini berarti semakin ada anak perusahaan maka perusahaan lebih cenderung tidak tepat waktu dalam penyampaian laporan keuangan ke OJK tetapi tidak memberikan pengaruh yang signifikan. Maka hipotesis yang menyatakan Kompleksitas Operasi berpengaruh terhadap ketepatan waktu pelaporan keuangan Ditolak.

3. Struktur Kepemilikan berpengaruh negatif dengan nilai $\beta=-6,257$ dan signifikan (nilai probabilitas $0.014>0.05$ ) terhadap ketepatan waktu penyampaian laporan keuangan. Ini berarti semakin tinggi kepemilikan publik maka perusahaan lebih cenderung tidak tepat waktu dalam penyampaian laporan keuangan ke OJK tetapi memberikan pengaruh yang signifikan. Maka hipotesis yang menyatakan Struktur Kepemilikan berpengaruh terhadap ketepatan waktu pelaporan keuangan Diterima.

4. Leverage berpengaruh negatif dengan nilai $\beta=-6,020$ ) dan signifikan (nilai probabilitas $0.001<0.05)$ terhadap ketepatan waktu penyampaian laporan keuangan. Ini berarti semakin tinggi Leverage perusahaan maka perusahan lebih cenderung tidak tepat waktu dalam penyampaian laporan keuangan ke OJK dan memberikan pengaruh yang signifikan. Maka hipotesis yang menyatakan leverage berpengaruh terhadap ketepatan waktu pelaporan keuangan Diterima. 


\section{Saran}

Dengan berbagai telaah dan analisa yang dilakukan serta berdasarkan keterbatasanketerbatasan penelitian, maka dapat diberikan saran sebagai berikut:

1. Mengambil periode pengamatan penelitian yang lebih panjang dengan jumlah sampel yang lebih banyak. Dengan periode pengamatan penelitian lebih panjang dan sampel yang lebih banyak diharapkan akan memprediksi ketepatan waktu pelaporan keuangan yang lebih baik.

2. Untuk peneliti selanjutnya, sebaiknya menambahkan jumlah variabel dengan demikian diharapkan akan memberikan kontribusi informasi yang lebih baik dan akurat untuk penelitian dimasa yang akan datang. Variabel yang mungkin bisa ditambahkan seperti Kualitas Auditor, Profitabilitas, opini auditor dan lain sebagainya.

3. Memperluas sampel yang terdaftar di BEI tidak hanya di perusahaan manufaktur melainkan perusahaan yang lainnya sehingga hasil yang diperoleh akan lebih dapat digeneralisasikan dan akan lebih menggambarkan kondisi sesungguh-nya selama jangka panjang.

\section{DAFTAR PUSTAKA}

Apri Fajar 2017, “Analisis Faktor-faktor Yang Mempengaruhi Ketepatan Waktu Penyampaian

Laporan Keuanga Interim (Studi Empiris Pada Perusahaan Manufaktur yang Terdaftar di Bursa Efek Indonesia Tahun 2013-2015)

Evi Herlyaminda, Muhammad Arfan, dan Darwanis. 2013. Pengaruh Financial Leverage, Likuiditas, Ukuran Perusahaan, dan Umur Perusahaan terhadap ketepatan waktu pelaporan keuangan (studi pada perusahaan real estate dan property yang terdaftar di bursa efek Indonesia). Jurnal Akuntansi Pascasarjana Universitas Syiah Kuala. Aceh

Ghozali, Imam, 2013. Aplikasi Analisis Multivariat dengan Program IBM SPSS 21. Edisi 7 , Penerbit Universitas Diponegoro, Semarang.

I G A P Bunga V dan Gayatri, 2018. "Pengaruh Profitabilitas, Ukuran Perusahaan, Struktur Kepemilikan, Leverage, Dan Umur Perusahaan Pada Ketepatan Waktu Pelaporan Keuangan pada perusahaan perbankan yang terdaftar di BEI"

Ikatan Akuntan Indonesia. 2009. Standar Akuntansi Keuangan, Salemba Empat, Jakarta.

Kasmir, 2012, Analisis Laporan Keuangan, Jakarta: PT.Raja Grafindo Persada.

Kieso, Weygandt, Warfield. 2002. Intermediate Accounting, Twelfth Edition, Erlangga, Jakarta.

Martius. 2012. Analisis Praktik Akuntansi Manajemen Pada Perusahaan Manufaktur (Studi Empiris di Kawasan Industri Batam)

Nasution, Khiyanda Alfian. 2013. Pengaruh Likuiditas, Ukuran Perusahaan, dan Profitabilitas Terhadap Ketepatan Waktu dalam Pelaporan Keuangan, Jurnal Fakultas Ekonomi Universitas Negeri Malang.

OJK, 2016. Penyampaian Laporan keuangan berkala emiten atau perusahaan publik,[Online],https://www.ojk.go.id/id/kanal/pasarmodal/regulasi/peraturanojk/Doc uments/Pages/POJK-Laporan-Tahunan-Emiten-Perusahaan-Publik/POJK-LaporanTahunan.pdf (diakses tanggal 11 Maret 2019 ).

Puput Safitri, 2013. "Analisis faktor-faktor yang mempengaruhi ketepatan waktu pelaporan keungan perusahaan manufaktur yang terdaftar di BEI"

R. Ait Novatiani, dan Nadia Putri Asri. 2016. Pengaruh Leverage, Ukuran Perusahaan, Opini Auditor dan Kompleksitas Operasi Perusahaan Terhadap Ketepatan Waktu Penyampaian Laporan Keuangan Perusahaan. Jurnal Akuntansi Bisnis dan Ekonomi Universitas Widyatama. Bandung 
Sugiyono. 2015. Metode Penelitian Bisnis. Bandung : Alfabeta.

Undang-Undang No. 8 Tahun 1995 tentang Peraturan Pasar Modal.

Widaryanti. 2011. “Analisis Faktor-faktor yang Mempengaruhi Ketepatan Waktu Corporate Internet Reporting pada Perusahaan-Perusahaan yang Terdaftar di BEI. Jurnal Ilmu Manajemen dan Akuntansi Terapan, Vol.2 No.2."

Widia Astuti \& Teguh Erawati, 2018 "Pengaruh Profitabilitas, Umur Perusahaan Dan Ukuran Perusahaan Terhadap Ketepatan Waktu Penyampaian Laporan Keuangan Perusahaan"

Yohan A Hutabarat, 2018. "PengaruhProfitabilitas, Likuiditas, Leverage, Dan Opini AuditTerhadap Ketepatan Waktu Penyampaian LaporanKeuangan Pada Perusahaan Manufaktur YangTerdaftar Di Bursa Efek Indonesia".

www.idx,co.id

www.idnfinancials.com

$\underline{\text { www.gt-tires.com }}$ 